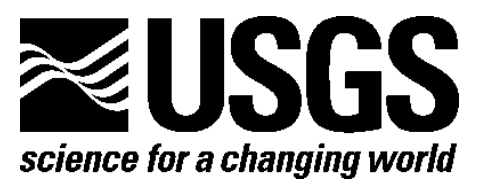

\title{
Mercury in U.S. Coal-Priorities for New U.S. Geological Survey Studies
}

By Allan Kolker

Open-File Report 2016-1033

U.S. Department of the Interior U.S. Geological Survey 


\section{U.S. Department of the Interior \\ SALLY JEWELL, Secretary}

\section{U.S. Geological Survey \\ Suzette M. Kimball, Director}

U.S. Geological Survey, Reston, Virginia: 2016

For more information on the USGS-the Federal source for science about the Earth,
its natural and living resources, natural hazards, and the environment-visit
http://www.usgs.gov/ or call 1-888-ASK-USGS (1-888-275-8747).
For an overview of USGS information products, including maps, imagery, and publications,
visit http://store.usgs.gov/.

Any use of trade, firm, or product names is for descriptive purposes only and does not imply endorsement by the U.S. Government.

Although this information product, for the most part, is in the public domain, it also may contain copyrighted materials as noted in the text. Permission to reproduce copyrighted items must be secured from the copyright owner.

Suggested citation:

Kolker, Allan, 2016, Mercury in U.S. coal--Priorities for new U.S. Geological Survey studies: U.S. Geological Survey Open-File Report 2016-1033, 21 p., http://dx.doi.org/10.3133/ofr20161033.

ISSN 2331-1258 (online) 


\section{Acknowledgments}

The author thanks the participants in the survey and phone conversation for providing guidance that enabled us to set priorities for future studies of mercury and associated trace elements in U.S. coals. Special thanks to Kevin Jones, U.S. Geological Survey (USGS) for transcribing the panel discussion and to José Vigil, USGS for compiling information on new Illinois Basin coal production in geographic information system (GIS) format. This investigation was supported by the USGS Energy Resources Program. 


\section{Contents}

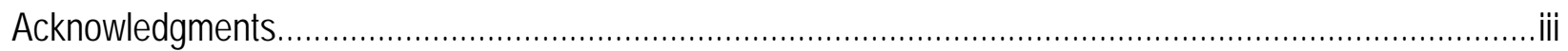

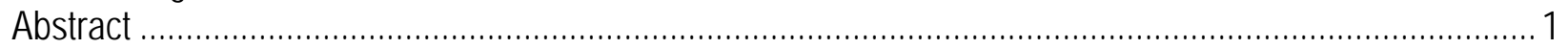

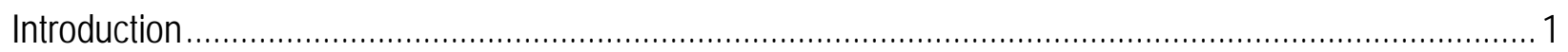

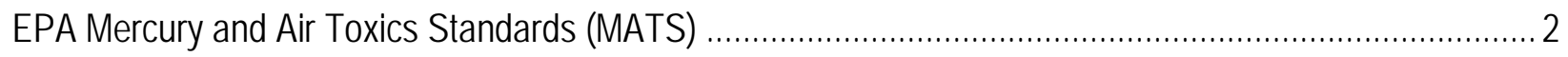

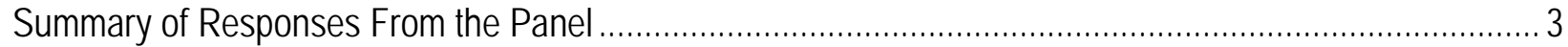

Should the USGS continue to study mercury and associated elements in coal? ................................... 3

What form should new USGS mercury studies take and how would they be used? ............................. 4

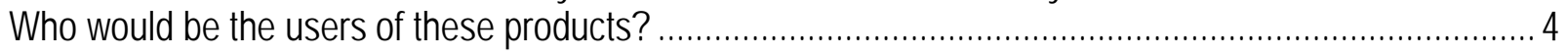

Should the USGS attempt to conduct a new nationwide assessment of mercury distribution

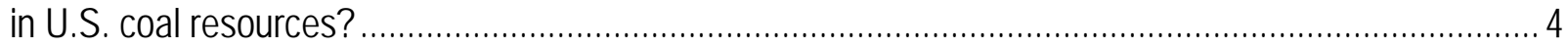

What U.S. study areas have the highest priority in the immediate term for new

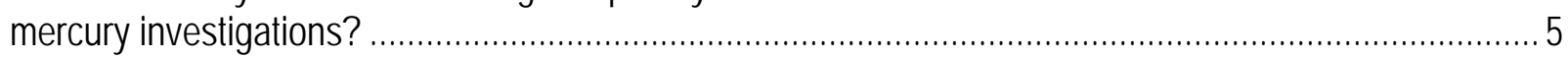

What sources of existing data are available that could be included in new USGS studies?..................... 6

How useful are data for in-ground and as-mined coal vs. coal deliveries? ........................................... 6

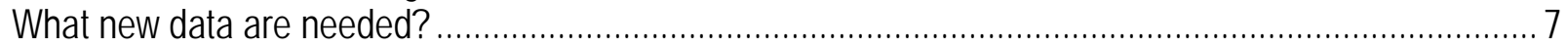

What QA/QC steps are needed to insure that new and existing data are usable and

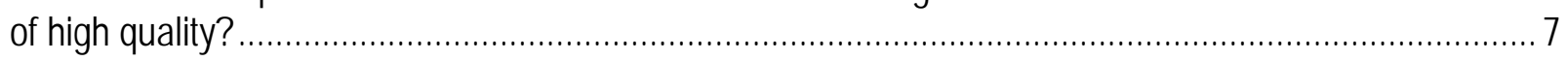

What related research questions could be addressed in new USGS studies? ................................... 8

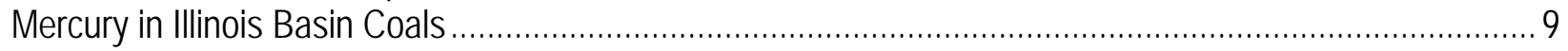

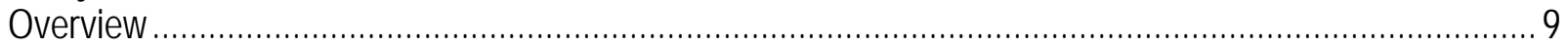

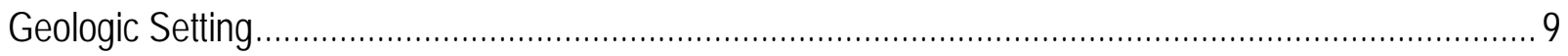

Past USGS Coal Resource Assessment................................................................................. 11

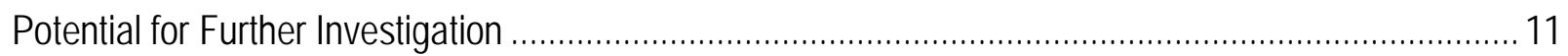

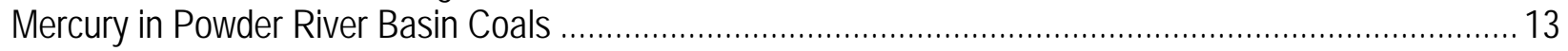

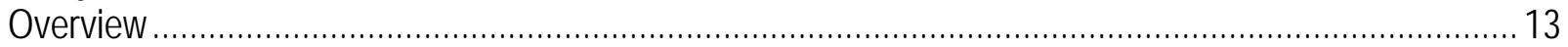

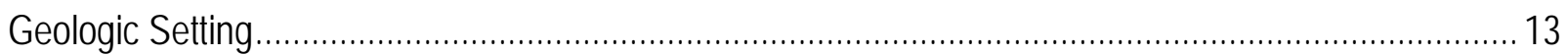

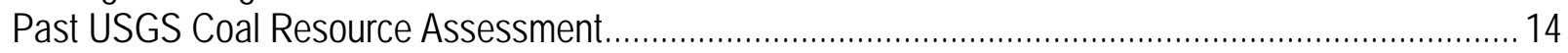

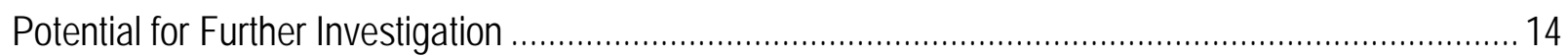

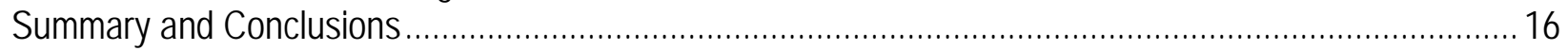

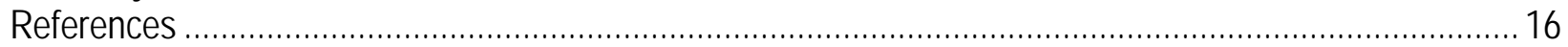

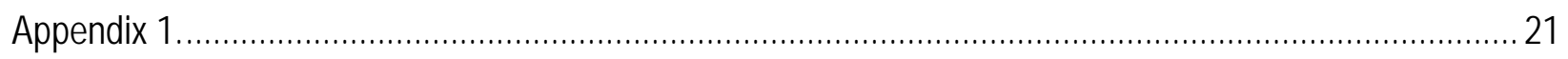

\section{Figures}

1. Plot showing U.S. annual coal production by coal basin from 2004 to 2013 for the Illinois Basin, Appalachian Basin and Powder River Basin.

2. Map showing Illinois Basin new coal mining activity between 2002 and 2014 as indicated by changes in the aggregate square miles per county of mined-out areas in the three main coal beds: Springfield, Herrin and Danville-Baker

3. Map showing distribution of mercury concentration in Illinois Basin Springfield coal .................... 12

4. Map showing mines and coal fields in the Powder River Basin .............................................. 15 


\section{Tables}

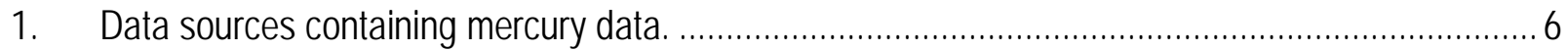

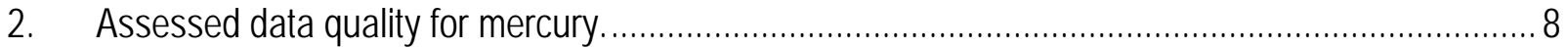

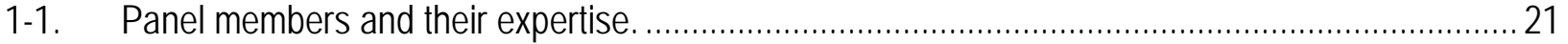

\section{Abbreviations}

$\begin{array}{ll}\text { ASTM } & \text { American Society for Testing and Materials } \\ \text { CAA } & \text { Clean Air Act } \\ \text { CAMR } & \text { Clean Air Mercury Rule } \\ \text { CVAA } & \text { cold vapor atomic absorption spectrometry } \\ \text { CVAFS } & \text { cold vapor atomic fluorescence spectroscopy } \\ \text { DOE } & \text { U.S. Department of Energy } \\ \text { DMA } & \text { direct mercury analysis } \\ \text { EPA } & \text { U.S. Environmental Protection Agency } \\ \text { FGD } & \text { flue gas desulphurization } \\ \text { GIS } & \text { geographic information system } \\ \text { ICP-MS } & \text { inductively coupled plasma mass spectrometry } \\ \text { ICR } & \text { Information Collection Request } \\ \text { INAA } & \text { instrumental neutron activation analysis } \\ \text { MACT } & \text { maximum achievable control technology } \\ \text { MATS } & \text { Mercury and Air Toxics Standards } \\ \text { ppm } & \text { parts per million } \\ \text { QA/QC } & \text { quality assurance/quality control } \\ \text { USGS } & \text { U.S. Geological Survey } \\ \text { XAFS } & \text { X-ray absorption fine structure }\end{array}$




\title{
Mercury in U.S. Coal-Priorities for New U.S. Geological Survey Studies
}

\author{
By Allan Kolker
}

\begin{abstract}
In 2011, the U.S. Environmental Protection Agency (EPA) introduced emissions standards, known as Mercury and Air Toxics Standards (MATS), for a range of toxic constituents from coal-fired utility power stations and other combustion sources. This report presents the findings of an expert panel convened in September 2014 to assess the role of the U.S. Geological Survey (USGS) in new coal investigations that would be useful to stakeholders under MATS. Panel input is provided as summaries of responses to a questionnaire distributed to participants. The panel suggests that the USGS continue its work on trace elements in coal and include more information about delivered coals and boiler feed coals, in comparison to previous USGS compilations that emphasized sampling representative of coals in the ground. To be useful under multipollutant regulatory standards, investigation of a range of constituents in addition to mercury would be necessary. These include other toxic metals proposed for regulation, such as arsenic, nickel, cadmium, and chromium, as well as the halogens chlorine and fluorine, which upon emission form harmful acid gases. Halogen determinations are also important because they influence mercury speciation in flue gas, which allows the effectiveness of mercury controls to be assessed and predicted. The panel suggests that the Illinois Basin and the Powder River Basin should have the highest priority for new coal quality investigations in the near term by the USGS, on the basis of current economic conditions and overall economic importance, respectively. As a starting point for new investigations, brief summaries of the distribution of mercury in each coal basin, and their potential for further investigation, are presented.
\end{abstract}

\section{Introduction}

Coal combustion is recognized as the single largest source category contributing to U.S. atmospheric mercury emissions (U.S. EPA, 2005). Combustion-sourced elemental mercury is also a global problem because of its long residence time in the atmosphere and resulting global transport (Pirrone and others, 2013, and references therein). Under the U.S. Environmental Protection Agency (EPA) Mercury and Air Toxics Standards (MATS), emissions limits and operational procedures were specified for U.S. coal-burning utilities to reduce emissions of mercury, other trace elements (Be, Cr, $\mathrm{Mn}, \mathrm{Co}, \mathrm{Ni}, \mathrm{As}, \mathrm{Se}, \mathrm{Sb}$, and $\mathrm{Pb}$ ), and acid gasses, including hydrofluoric acid (HF) and hydrochloric acid (HCl) (U.S. EPA, 2012). Whereas updates to the original provisions of MATS are pending following a 2015 Supreme Court ruling, it is likely that a multipollutant approach will be retained in the revised rule. Over a period of more than 20 years leading to the introduction of MATS, the U.S. Geological Survey (USGS) has been an active participant in investigations of toxic gaseous emissions from coal combustion, especially on the input side, providing detailed information on the occurrence and distribution of mercury and other trace constituents in coal. The USGS has unique capabilities to 
quantify the origin and distribution of mercury and trace constituents in coal (for example, Diehl and others, 2012; Kolker, 2012), and conducts basin-scale studies to evaluate the extent and quality of U.S. coal resources (for example, Ruppert and Ryder, 2014; Luppens and others, 2015). These USGS studies are useful to a range of stakeholders, including those seeking to reduce mercury and trace metal emissions to the environment, as intended by the EPA in its rulemaking effort.

With introduction of MATS, it may be appropriate for the USGS to prioritize future studies of mercury and other trace constituents in coal whose emissions are limited under the proposed regulation. To help address the USGS role and determine how best to serve the needs of stakeholders, a panel of experts on mercury emissions from U.S. coal and related topics was convened in September 2014. The panel consisted of utility operators, coal industry representatives, industry consultants, academic researchers in the energy sector, and the EPA, in addition to USGS participants with appropriate expertise in energy geochemistry and related topics (appendix 1, table 1-1).

Participation by the panel included taking part in a conference call to identify priorities for new USGS studies and (or) providing written responses to a series of questions about the role of the USGS going forward under the proposed EPA regulations. This report summarizes the findings of the expert panel. Although a range of suggestions was put forth, there was a consensus by the panel that continued USGS studies of mercury and trace elements in U.S. coals were needed to provide a better understanding of the substances to be regulated under MATS and related aspects such as mercury control. The panel also concluded that as-received sampling representative of commercial coals delivered to power stations was much more important to utilities, the primary users of any subsequent USGS mercury assessment, than in-ground sampling traditionally conducted by the USGS.

Two of the most economically important coal producing areas, the Powder River Basin of Wyoming and Montana, and the Illinois Basin, comprising parts of Indiana, Illinois, and western Kentucky, were identified by the panel as having the highest priority in the near term for new USGS coal studies, including those for mercury and trace elements. In each case, past USGS coal resource assessments provide a foundation for new investigations in these study areas. Incorporating newer tools, such as laser ablation inductively coupled plasma mass spectrometry (ICP-MS), and mercury isotopic data, may be especially helpful for investigating geologic controls on the distribution of mercury and associated elements. Methodology for these investigations includes (1) integration and evaluation of existing data from the past USGS coal assessment and other sources; (2) where necessary, acquisition and analysis of new samples; and (3) tests of geostatistical and other approaches to predicting the distribution of mercury and other constituents in raw coal and the extent of their reduction during coal preparation. As a starting point, reviews of existing information concerning mercury in coals of each basin are included in this report, together with consideration of its potential for further study.

Preliminary work in the Illinois Basin has included sampling of a commercial coal preparation circuit to help demonstrate the extent of mercury reduction that can be expected.

\section{EPA Mercury and Air Toxics Standards (MATS)}

The 1990 amendments to the Clean Air Act (CAA) authorized an expanded Federal role in controlling toxic air pollutants (Hutson, 2015). Following extensive study in the 1990s of the effect of mercury emissions from coal-fired power plants and other emissions sources, the EPA determined in 2000 that it was “appropriate and necessary” to limit these emissions (U.S. EPA, 2000). Emissions limits proposed by the EPA under Section 112 of the CAA were based on the maximum extent that emissions were controllable, referred to as maximum achievable control technology (MACT). This legislation was ultimately reversed and replaced in 2005 by new legislation under Section 111 of the CAA, known as the Clean Air Mercury Rule (CAMR; Hutson, 2015). The CAMR established emissions 
performance standards for new and existing coal-fired electric generating units. Court challenges led to the abandonment of CAMR in 2008 before it was ever implemented. Further litigation, on the failure of EPA to promulgate final emissions standards under CAA section 112, was settled with EPA agreeing to issue final, MACT-based emissions standards for coal- and oil-fired generating units by December 2011.

The EPA issued MATS in 2011, which represented final, more comprehensive emissions standards for mercury and air toxics. These standards include emissions limits for mercury, other toxic metals, such as arsenic, cadmium, lead, nickel, and chromium, and for halogen-based acid gases, including hydrochloric acid and hydrofluoric acid. Also specified within MATS are work practices limiting emissions of toxic organic compounds, such as benzene and dioxins (U.S. EPA, 2012; Hutson, 2015). Following promulgation of the final MATS rule, the EPA was petitioned to reconsider some of its provisions, such as the achievability of standards specified for new generating units. Revised emission limits for new sources were finalized in 2013. The EPA then reconsidered other specific technical and reporting issues within MATS, each resulting in updates to the final rule. In April 2015, the EPA announced it had completed its review of all remaining requests to reconsider aspects of MATS, thereby clearing the way to proceed with MATS implementation. However, implementation of MATS was halted in a June 2015 ruling by the U.S. Supreme Court, stating in a 5-4 decision that the cost of MATS compliance was not properly considered in the rulemaking process (Supreme Court of the United States, 2015). With this decision, the Supreme Court returned MATS to the U.S. Court of Appeals for the District of Columbia Circuit. In December 2015, the lower court remanded the issue back to the EPA to amend MATS to comply with the Supreme Court ruling.

\section{Summary of Responses From the Panel}

Participants in the mercury in U.S. coal panel discussion and their associates were invited to submit written responses to a series of questions addressing priorities for continued USGS research on mercury in U.S. coals. The questionnaire also asked respondents to specify potential users of related USGS research products and prioritize U.S. study areas for new investigations in the near term. The responses and suggestions of the panel are summarized in the following sections. Overall, the panel supports continued USGS investigation of the geochemistry of U.S. coal in support of emissions limits specified under MATS but suggests that the traditional emphasis on in-ground sampling be expanding to include delivered coals. The panel identified the Illinois Basin and the Powder River Basin as the highest priority study areas and suggested that investigating one or more of these prioritized areas should take precedence in the near term over a new nationwide investigation. Discussion points included in the USGS questionnaire and summaries of responses to each question by the panel are given in the remainder of this section.

\section{Should the USGS continue to study mercury and associated elements in coal?}

There is a consensus among the panel members that the USGS is an important source of information concerning trace-element concentrations in coal whose emissions are to be regulated. This is especially relevant, because one of the most widely used EPA databases, the 1999 EPA Information Collection Request (ICR) database; U.S. EPA, 2003), did not include test results for metals other than mercury. More information about halogens is needed because of their contribution to mercury oxidation and capture and their influence on speciation beyond the stack, which determines the pattern of mercury deposition around emission sites. In coal-fired power plants, halogens promote oxidation of elemental mercury, allowing it to form gaseous mercury-halogen complexes, and this halogen-bound mercury is 
much more readily captured by air pollution control devices (Senior, 2015; Kolker and others, 2012). Halogens are also important because emissions of two halogen-based acid gasses, $\mathrm{HCl}$ and $\mathrm{HF}$, were to be limited under the MATS regulations. A variety of analytical methods have been applied for halogen analysis, and detection limits have improved with the most recent approaches. New data for halogens in coal obtained using the most appropriate methods, together with a critical review of existing data, would be helpful in assessing mercury capture. Although estimating total emissions of mercury will be simplified upon installation of mercury monitors stipulated under MATS, the USGS can still play an important role in these other aspects.

\section{What form should new USGS mercury studies take and how would they be used?}

There was agreement among respondents that data for mercury and other constituents be made available in an online database accessible to all interested parties. Presentation in a spreadsheet format would allow for data sorting and manipulation to identify trends. In the same database, data could be expressed on an as-shipped (moisture-containing) basis, which might be useful to utilities, and on a dry basis, which would be useful for comparing results. Graphical display in a geographic information system (GIS) format would be helpful for statistical and predictive analysis of results, provided sampling was available at a sufficiently high density. New sampling could be targeted so as to fill in areas with sparse coverage, as well as to address geologic questions.

\section{Who would be the users of these products?}

Compilation of results concerning the elemental composition of U.S. coals would be useful to utilities seeking to identify better emission control strategies for specific coals. Information contained in the database is also needed by the cement industry, which operates kilns coming under emissions limits similar to MATS. The results would also be of use to the engineering community engaged in combustion research and development of new control technologies for toxic emissions. Other potential users mentioned in the survey include mining companies, non-governmental organizations, other Government agencies, and Congress.

\section{Should the USGS attempt to conduct a new nationwide assessment of mercury distribution in U.S. coal resources?}

Responses to this question were mixed. Some participants felt that existing EPA and USGS coal databases adequately characterize mercury distribution in U.S. coals. Others felt that such an effort by the USGS would be beneficial in monitoring the effectiveness of mercury emissions control under MATS, especially if data for halogens, affecting the controllability of mercury, were included. Inclusion of up-to-date information about trace elements whose emissions were limited under MATS was also considered a necessary part of any new mercury assessment. In questioning whether a nationwide effort to characterize mercury distribution was needed, some panel members noted that thousands of new samples would be required for the scale of this effort to be comparable to that of existing data sources, and that for most regions, existing results indicate within-bed mercury variation is almost as great as between-bed variation. Furthermore, even under MATS, utilities are unlikely to select coal based only on its mercury content. Other quality factors, such as ash yield, sulfur content, and heating value are likely to predominate. 


\section{What U.S. study areas have the highest priority in the immediate term for new mercury investigations?}

The panel was asked to identify and prioritize one or more U.S. coal basins for further studies of mercury and associated elements. In nearly every response to this question, the Illinois Basin and Powder River Basin were mentioned as top candidates. High sulfur Illinois Basin coal is currently the most cost competitive U.S. coal source (James, 2012; Fiscor, 2012; Miller, 2014). Because of its cost advantage and the proximity of many Ohio Valley and southeastern power stations, coal production in the Illinois Basin is increasing despite an overall decrease in U.S. coal production and the fraction of U.S. generating capacity from coal as it is supplanted by gas-fired generation (fig. 1). With greater implementation of sulfur dioxide scrubbers and retirement of older, coal-fired power stations lacking scrubbers, the high sulfur content of Illinois Basin coals has become less of an impediment.

Demand for Powder River Basin coals remains high because of its low sulfur content, but after decades of expansion, production of Powder River Basin coal has decreased slightly in recent years (U.S. Energy Information Administration, variously dated; fig. 1). The Powder River Basin continues to be the single largest U.S. coal source. New studies of either basin could benefit from past USGS coal resource assessments (discussed herein for Illinois Basin and Powder River Basin coals). Extensive reserves in each basin ensure its economic importance for decades to come.

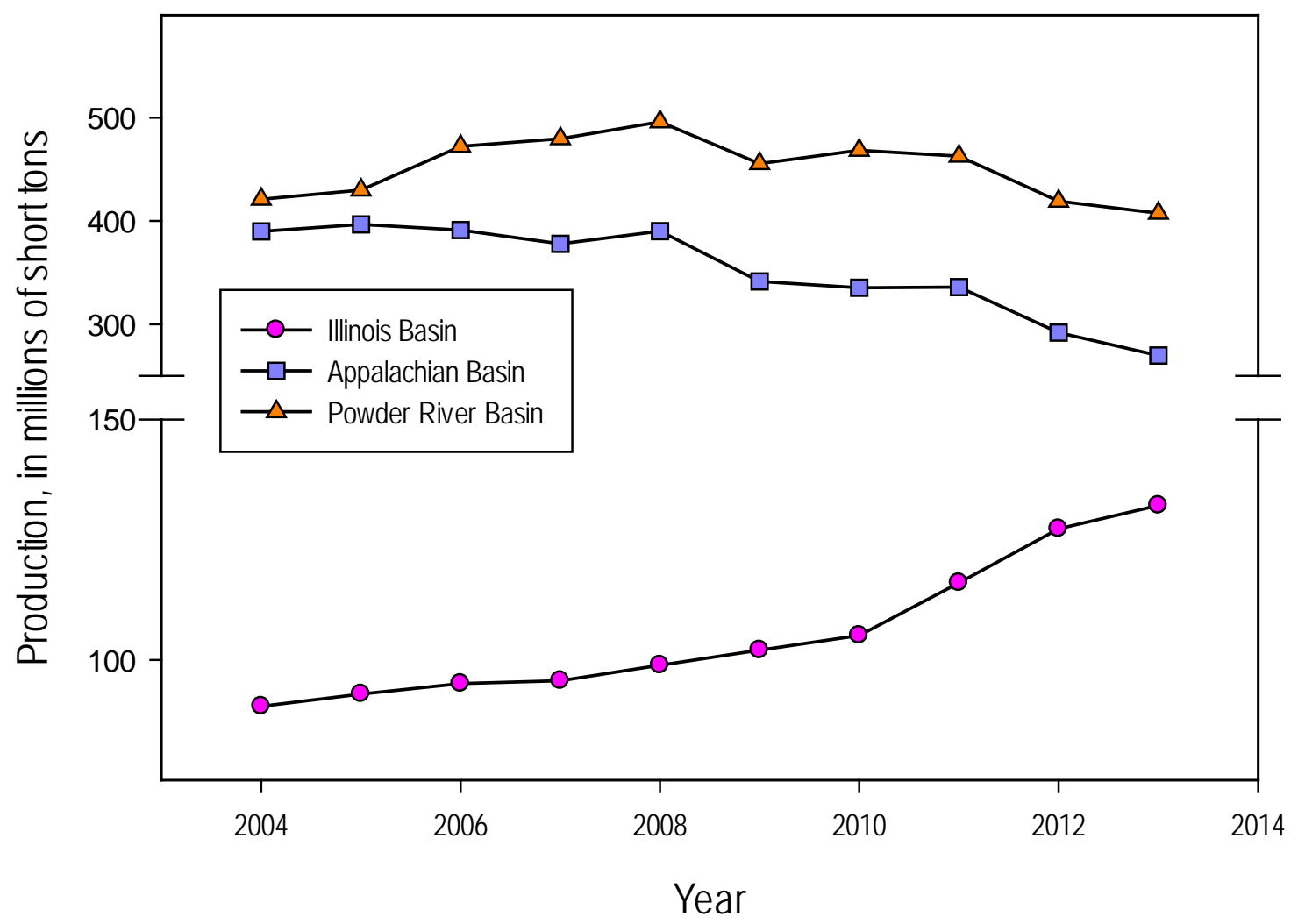

Figure 1. Plot showing U.S. annual coal production by coal basin from 2004 to 2013 for the Illinois Basin, Appalachian Basin and Powder River Basin. Plot includes a break in the vertical scale omitting production levels from 150 to 250 million short tons. Plot shows increasing production of Illinois Basin coals despite high sulfur contents and increasing gas-fired power generation. Coal production data from U.S. Energy Information Administration (variously dated). 


\section{What sources of existing data are available that could be included in new USGS studies?}

Existing EPA and USGS databases provide large data resources for characterizing U.S. coal (table 1). The contents of each of these databases are reviewed by Kolker and Quick (2015, table 2.1). The EPA databases are based on analysis of coal shipped to utilities, generated for their 1999 and 2010 rulemaking ICRs (U.S. EPA, 2003, 2011a, b), whereas USGS databases, such as the USGS COALQUAL database (Bragg and others 1998) are based on analysis of samples representing coal in the ground. In addition to the EPA and USGS databases, Pennsylvania State University maintains a national coal database of coal quality parameters. Other statewide databases are available, including those for the States that compose the Illinois Basin (table 1); these databases contain data for coal quality and trace elements including mercury.

Table 1. Data sources containing mercury data.

[EPA, U.S. Environmental Protection Agency; ICR, Information Collection Request; MATS, Mercury Air Toxics Standards; USGS, U.S. Geological Survey]

National databases

EPA databases:

1999 EPA ICR (Hg and Cl) http://www.epa.gov/ttn/atw/combust/utiltox/utoxpg.html

2010 EPA ICR for MATS http://www.epa.gov/ttn/atw/utility/utilitypg.html

USGS COALQUAL database http://energy.er.usgs.gov/coalqual.htm

Penn State database http://www.energy.psu.edu/copal/index.html

Illinois Basin sources

USGS Coal Resource Assessment http://pubs.usgs.gov/pp/p1625d/

State databases:

Kentucky http://kgs.uky.edu/kgsweb/DataSearching/Coal/Quality/QualitySearch.asp

Illinois http://isgs.illinois.edu/research/coal/maps

Indiana http://igs.indiana.edu/Coal/Mercury.cfm

Powder River Basin sources

USGS Coal Resource Assessment http://pubs.usgs.gov/pp/1809/ (no coal quality data)

USGS Open-File Report http://pubs.usgs.gov/of/2007/1116/

\section{How useful are data for in-ground and as-mined coal vs. coal deliveries?}

The USGS has traditionally provided geochemical data for coal beds in the ground, as opposed to coal delivered to powerplants, which has been the focus of EPA coal databases. Some survey respondents indicated that new results for in-ground coal would be useful, especially in showing the within-bed variation that might be expected for specific coals. Overall, the panel considered results for coals in the ground to be less useful than data for delivered coals. Consideration of coals only on an inground basis does not take into account the effect of coal washing or other pre-combustion processing. This can be especially important for bituminous coals - such as those in the Illinois Basin, where prepared coal is used both in power stations that do not have scrubbers and in those that do have scrubbers - to reduce mineral matter and increase heating value of the coal. Preparation of bituminous coals typically reduces mercury contents as a co-benefit to reduction of mineral matter and increased 
heating value. Subbituminous coals of the Powder River Basin are relatively low in sulfur and mercury content and are generally combusted without preparation. In addition to sampling delivered coals, some panel members emphasized that sampling of pulverized coals feeding the boiler is needed, because this step is critical in determining emissions.

\section{What new data are needed?}

The panel noted that additional information is needed about the modes of occurrence and (or) mineralogical controls of mercury distribution in coal. A better understanding of how mercury is bound in coal could support development of new pretreatment procedures specific to mercury, rather than relying on reduction achieved as a co-benefit to processes intended to reduce mineral matter, overall. Acquisition of mercury isotopic data would provide a better understanding of the geologic controls of mercury in a coal basin. For example, in the Illinois Basin, mercury isotopic data suggest that syngenetic (depositional) mercury sources are distinct from epigenetic (hydrothermal) mercury sources (Lefticariu and others, 2011). These results contribute to an improved understanding of the sources and controls of mercury in a coal basin.

\section{What quality assurance/quality control (QA/QC) steps are needed to ensure that new and existing data are usable and of high quality?}

In generating new analyses, data quality is ensured by running sufficient numbers of certified standards, together with replicate analyses and total analytical blanks. For mercury, current bulk analytical methods most widely used in coal analysis include thermal decomposition, amalgamation, and atomic absorption spectrophotometry, collectively known as direct mercury analysis (DMA; U.S. EPA, 2007), and cold vapor atomic absorption spectrometry (CVAA; Aruscavage and Moore, 1989; O’Leary, 1997). For the USGS COALQUAL database, mercury data generated before 2005 were determined by CVAA and more recent results by DMA (Kolker and Quick, 2015). Other methods, such as cold vapor atomic fluorescence spectroscopy (CVAFS) and instrumental neutron activation analysis (INAA), have been applied in specific cases, as discussed in Kolker and Quick (2015). For mercury isotopic data, cold vapor mercury generation is used together with a multi-collector ICP-MS (Lefticariu and others, 2011). Cold vapor mercury generation can also be used in bulk mercury analysis by means of ICP-MS, provided the sample can be brought into solution without loss of mercury.

In assessing the quality of published results for mercury, the appropriateness of the method is the first consideration. If the method is appropriate in terms of its detection limit and the quality assurance/ quality control (QA/QC) data, such as standard values obtained, are provided and found to be within their certified range, then there should be a high degree of confidence in the results (table 2). If methods are not specified or sufficiently sensitive, then the data collected using such methods should not be used. Examples of less sensitive methods for mercury analysis include emission spectrometry/spectroscopy (Golightly and others, 1987), and X-ray fluorescence spectrometry (Taggart, and others, 1987); both methods were extensively used by the USGS until the early 1980s. Conducting round robin testing with selected well-characterized materials can be useful for identifying laboratory biases. As noted by one panel member, additional potential database pitfalls beyond the actual analysis can result where there is uncertainty or inconsistency in (1) the reporting of sample origin, (2) the basis for expressing coal moisture content, and (or) (3) the inclusion of unrepresentative weathered or noncommercial samples. 
Table 2. Assessed data quality for mercury.

[Relative quality of mercury data are ranked from highest (1) to lowest (5). Use of data with ranking below (3) is questionable. Abbreviations: DMA, direct mercury analyzer; CVAA, cold vapor atomic absorption; CVAFS, cold vapor atomic fluorescence; INAA, instrumental neutron activation analysis; ICP-MS, inductively coupled plasma mass spectrometry; QA/QC, quality assurance/quality control; D.L., detection limit]

\begin{tabular}{cl}
\hline Rank & \multicolumn{1}{c}{ Mercury data } \\
& \\
\hline 1 & DMA, CVAA, CVAFS, INAA or ICP-MS* + QA/QC data (standards + replicates + D.L.) \\
2 & DMA, CVAA, CVAFS, INAA or ICP-MS* but no QA/QC \\
3 & Other method + QA/QC data within appropriate limits \\
\hline 4 & Other method, no QA/QC data \\
\hline
\end{tabular}

*Analysis of digested whole coal.

Some panel members noted that the methods used for halogen determinations have evolved similarly to those for mercury, with considerable improvement in detection limits. This is especially important in determinations for low-rank coals typically having halogen concentrations that approach or are below detection limits for widely used ASTM methods. A long-time ASTM method for chlorine in coal (ASTM International, 2013) utilizes sample combustion in an oxygen bomb, followed by chlorine measurement in solution using an ion-selective electrode. This method has a detection limit for chlorine of about 100-200 parts per million (ppm), with precision decreasing as the detection limit is approached (EPRI, 2000). An alternate method using oxidative hydrolysis microcoulometry (ASTM International, 2015) has a lower detection limit for chlorine by about a factor of 10, as shown in a comparative study (EPRI, 2000). Further improvement in the detection of halogens in coal, with simultaneous measurement of multiple halogens, has been obtained in recent studies using ion chromatography (Peng and others, 2012).

\section{What related research questions could be addressed in new USGS studies?}

Understanding coal washing in terms of the fate of mercury and trace elements, in both prepared coal and coal washing refuse, is of considerable interest to the panel. The USGS has conducted similar investigations, including a recent study of South African coals prepared for export (Kolker and others, in press) showing reduction of mercury in a simulated preparation procedure and residence of mercury in pyrite removed by coal preparation. In addition to coal washing, understanding the distribution and potential element mobility from coal ash remains an important issue identified by the panel, both in the beneficial use of coal ash and in its storage within landfills and impoundments. Recent work on this topic by the USGS shows that potential element mobility is strongly influenced by redox conditions, which vary considerably in the environment (Deonarine and others, 2015). In addition to these areas of investigation, there may be some opportunity to investigate the fate of mercury in flue gas desulphurization (FGD), both in reuse and storage, but the panel also notes that this topic has been investigated to a large extent by other agencies, including EPA and Department of Energy (DOE). Central to the implementation of MATS or comparable limits is the larger question of what impact the new standards will have on mercury and trace metal atmospheric deposition from U.S. combustion sources. 


\section{Mercury in Illinois Basin Coals}

\section{Overview}

According to the U.S. Energy Information Administration, Illinois Basin coal production has increased by 46 percent over the last 10 years while coal production in the Appalachian and Powder River Basins have each decreased in recent years (fig. 1). Based on the suggestions of the panel, the Illinois Basin is perhaps the most advantageous region for followup studies of a U.S. coal basin, for chemical constituents having relevance under MATS. In addition to the economic importance of new mining activity in the Illinois Basin, other factors contributing to its suitability for MATS-related studies include (1) the potential for characterizing and predicting the impact of coal preparation on reducing mercury and other potentially harmful constituents; (2) the potential for developing algorithms to predict mercury and halogen contents in Illinois Basin coals; (3) existence of a past USGS coal resource assessment of the basin (Hatch and Affolter, 2002); and (4) the extended length of time (15 years) since the last assessment, which makes an update desirable (fig. 2).

\section{Geologic Setting}

The Illinois Basin contains a sequence of Paleozoic sediments ranging in age from Cambrian to Pennsylvanian. The sequence thickens from north to south to a maximum thickness of about 14,000 feet in the deepest part of the basin in southern Illinois (Willman and others, 1975). Parts of the basin extend into southwestern Indiana and western Kentucky. In Illinois, the most economically important coals are present within the Pennsylvanian Carbondale Formation, including the Colchester (No. 2); the Springfield (No. 5), the Herrin (No. 6), and the Danville (No. 7) listed in ascending stratigraphic order (Willman and others, 1975). Major structures within the basin include the north-northwest-trending LaSalle anticlinal belt in the east-central part of the basin, and in the southern part of the basin, the north-trending Du Quoin monocline and the west-trending Cottage Grove-Rough Creek fault zone (fig. 2 in Hatch and others, 2002).

The extreme southeastern part of the basin is marked by faulting associated with mineralization in the Illinois-Kentucky fluorite district (Heyl and others, 1965; Willman and others, 1975; Hatch and others, 2002). Also in this vicinity, domal structures such as the Hicks Dome result from underlying intrusive magmatism (Willman and others, 1975; Denny and others, 2015). Thermal pulses resulting from magmatism, localized hydrothermal activity, or regional structurally-controlled hydrothermal fluid flow have locally increased the rank of coal in the far southeastern portion of the basin (Hower and Gayer, 2002). Apart from changes to coal rank, the chlorine concentrations in this part of the basin are highest in proximity to structures providing conduits for hydrothermal fluid flow (Hower and others, 1991), with corresponding enrichment in trace elements such as chromium, vanadium, nickel, arsenic and zinc (Hower and others, 1991; Hower and Gayer, 2002; Goldhaber and others, 2003). More detailed investigation is needed to determine the influence of magmatic and hydrothermal activity in the southeastern part of the basin on the complete suite of elements proposed for regulation under MATS, especially in areas of new mining activity. 


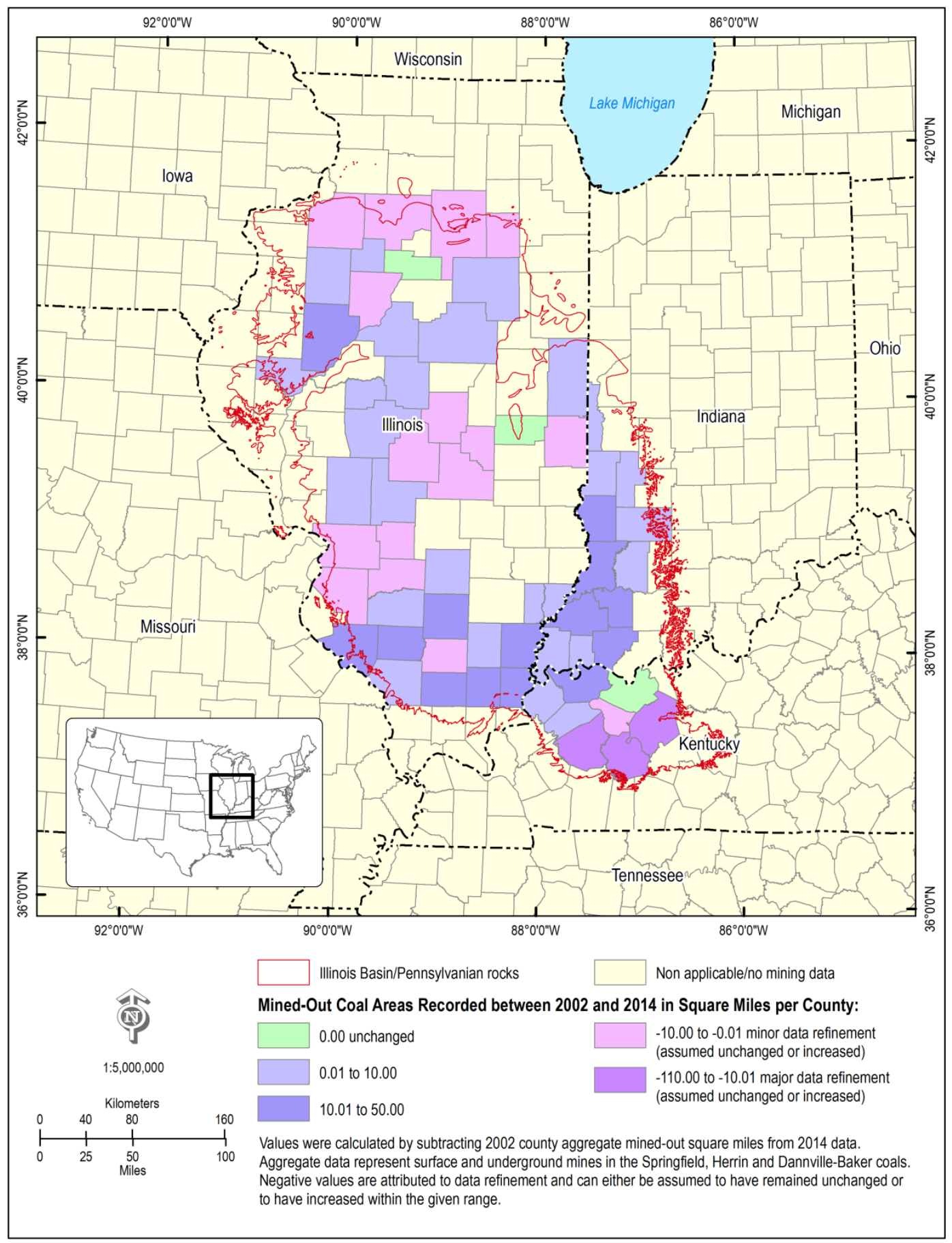

Figure 2. Map showing Illinois Basin new coal mining activity between 2002 and 2014 as indicated by changes in the aggregate square miles per county of mined-out areas (surface and underground) in the three main coal beds: Springfield, Herrin and Danville-Baker. Negative values for some counties result from changes in how minedout areas are recorded, especially for Kentucky. Data from Illinois State Geological Survey (2014), Kentucky Geological Survey (2015), and Indiana Geological Survey (2015). 


\section{Past USGS Coal Resource Assessment}

A USGS coal resource assessment in the Illinois Basin completed in 2002 included categorized estimates of coal resources remaining in the following coal beds: the Springfield (No. 5), Herrin (No. 6), and the Danville (No. 7) and its equivalent in western Kentucky, the Baker (No. 13) coal, hereafter referred to as, the "Danville-Baker coal” (Hatch and Affolter, 2002; Hatch and others, 2002). To obtain these estimates, digital databases were compiled from all publicly available point-source data on coal thickness and depth, in cooperation with the State Geological Surveys of Illinois, Indiana, and Kentucky. Available coal quality data, including ash yield, sulfur, heating values, and major, minor, and trace-element data were also compiled. State and basinwide maps were prepared showing the extent; depth and thickness of the coals assessed; and distribution of coal quality parameters, including mercury (fig. 3). Based on estimates for the assessed coal beds, basinwide, less than 20 percent of the coal whose production was not limited by land use or technological restrictions had already been mined at the time of the assessment (Hatch and others, 2002).

For each coal assessed, trace-element data were included for about 10 percent of the samples having proximate analyses. For example, for the Herrin (No. 6) coal, out of more than 2,300 samples having ash yield, sulfur and heating values, 216 samples had determinations for arsenic and 206 samples had values for mercury (Hatch and others, 2002). Nonetheless, average mercury values obtained for the Springfield, Herrin, and the Danville and Baker coals (0.12, 0.12, and $0.11 \mathrm{ppm}$, respectively), are very similar to averages for mercury in Illinois coals obtained in earlier investigations (Ruch and others, 1971; Gluskoter and others, 1977). More detailed sampling in Indiana and Kentucky, especially for the Springfield coal (Mastalerz and Drobniak, 2005; Hower and others, 2005) yielded similar average values, but showed that within-bed mercury variation can be almost as great as basinwide variation (Hower and others, 2005).

\section{Potential for Further Investigation}

Building on the compilations obtained in the 2002 assessment could allow further investigation of the controls and distribution of mercury and trace elements in Illinois Basin coals. This would include compilation of new (since 2002) analyses available in the public domain, evaluation of their quality using criteria noted previously, and where appropriate, conducting new sampling. Inclusion of methods such as mercury isotopic data and laser ablation ICP-MS analysis will help scientists determine regional controls on mercury and associated elements. Presentation of the results in GIS format could be used to show new mining activity since the 2002 resource assessment (fig. 3) and help make basin-scale maps or predictions of relevant coal quality parameters, such as mercury and chlorine contents.

Past investigation of chlorine and alkalis in Illinois Basin coals was prompted by concern over corrosion and fouling of coal-fired boilers caused by these constituents. In determining the distribution of sodium and chlorine in Illinois Basin coals, Gluskoter and Rees (1964) and Gluskoter (1967) recognized that these constituents increased regularly with depth, suggesting that chlorine in the Herrin (No. 6) coal was controlled by exchange with formation waters. Using X-ray-absorption fine-structure (XAFS) spectroscopy, Huggins and Huffman (1995) showed that in bituminous coals, including the Herrin (No. 6) coal, chloride anions are contained within moisture adhering to coal macerals. As the chlorine content of formation waters increases with depth, equilibration of coal macerals with formation waters explains the observed increase in the chlorine content of coal with depth in the Illinois Basin and elsewhere. Apart from depth, structural controls influencing the migration of hydrothermal fluids, especially in the southeastern part of the basin, need to be taken into account in predicting chlorine content (Hower and others, 1991; Goldhaber and others, 2003). 


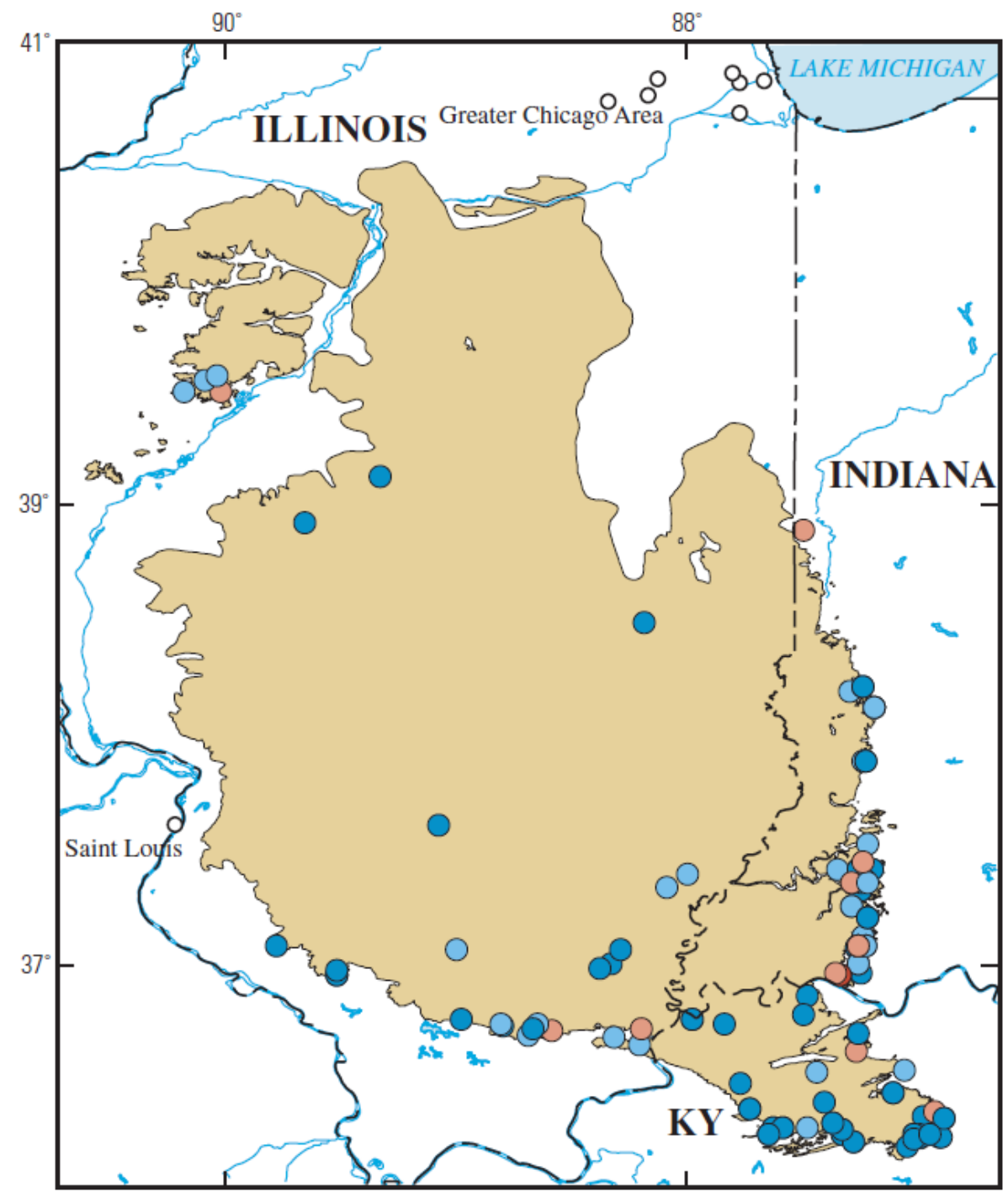

EXPLANATION

Mercury ppm

(whole-coal basis)

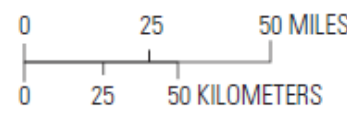
$0.01-0.1$
$0.1-0.22$
○ $\quad 0.22-0.47$
○ $\quad 0.47-1.2$

Springfield Coal extent

River, lake, or reservoir

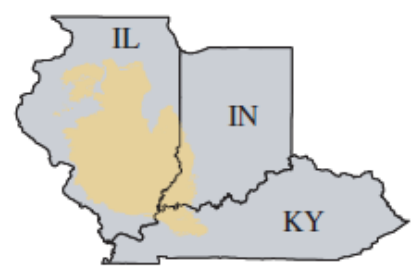

Figure 3. Map showing distribution of mercury concentration in Illinois Basin Springfield coal (from Hatch and others, 2002). [ppm, parts per million] 
Prediction of other halogens in Illinois Basin coals may also be plausible. There is considerable interest in levels of bromine in coal, because on a molar equivalent basis, bromine is much more effective than chlorine as an oxidizer of mercury in flue gas (Senior, 2015). Bromine in coal has a similar mode of occurrence to chorine, and for Illinois coals, in relatively consistent proportion, comprising about 1 percent of the amount of chorine present (Huggins and Huffman, 1995; Kolker and others, 2015, and references therein). Thus, addition of high-quality analyses for a more complete suite of halogens to existing halogen data for Illinois Basin coals could potentially help constrain predictions of halogen distribution.

The effect of coal preparation on trace elements in Illinois coals has been examined in several past studies. Demir and others (1997) compared results for conventionally cleaned as-shipped samples, primary of Herrin and Springfield coals, to channel samples of Illinois coals collected previously by the Illinois State Geological Survey. Demir and others (1997) found reductions of approximately 20 percent for a range of hazardous air pollutants by conventional procedures and, potentially, greater reductions by froth flotation. Using XAFS, Huggins and others (2009) investigated the mode of occurrence of a range of elements in an Illinois No. 6 coal and corresponding fractions prepared by physical separation at a commercial coal preparation operation. Mercury mode of occurrence was not determined in this study, because its concentration is below quantification by XAFS. This study found that arsenic is almost entirely associated with pyrite or as arsenate formed by pyrite oxidation (Huggins and others, 2009). Reconnaissance studies using laser ablation ICP-MS indicate residence of both arsenic and mercury in pyrite in the Herrin (No. 6) coal (Kolker and others, 2006). Follow up work on new samples using similar approaches could help determine the feasibility of developing algorithms for predicting mercury content in Illinois Basin coals, together with other trace elements of interest.

\section{Mercury in Powder River Basin Coals}

\section{Overview}

The Powder River Basin contains some of the most extensive deposits of low-sulfur, low ash, subbituminous coal in the world (Luppens and others, 2013, 2015). Current production of Powder River Basin coal composes approximately 40 percent of U.S. coal production (Luppens and others, 2015; Carroll, 2014), with most coming from the Gillette coal field at the eastern margin of the basin in Wyoming. Because of its low sulfur content, Powder River Basin coal is shipped to power stations in all but the eastern third of the country, comprising a total of 30 States (U.S. Energy Information Agency, 2014). Increasingly, Powder River Basin coal is produced for export to international customers (U.S. Energy Information Agency, 2014; Carroll, 2014).

\section{Geologic Setting}

The Powder River Basin is an elongate north-northwest trending, asymmetric sedimentary basin containing a thick sequence of lower Tertiary strata, primarily including the Paleocene Fort Union Formation and the Eocene Wasatch Formation. Most of the economic coal beds are in the WyodakAnderson coal zone in the Tongue River Member of the Fort Union Formation (Luppens and others, 2015, and references therein). At the eastern margin of the basin, coal beds are thick, shallow, and gently dipping, allowing near-surface coal to be extracted in large surface-mining operations. At the western margin of the basin, strata, including coal beds, are more steeply dipping, making them less accessible. 


\section{Past USGS Coal Resource Assessment}

A recent USGS coal resource assessment in the Powder River Basin primarily sought to provide geologically-based estimates of current in-place coal resources (Luppens and others, 2013, 2015). The overall assessment was conducted in four sections (assessment areas), including the Gillette coal field in the south-central part of the basin, the Northern Wyoming Powder River Basin, the Southwestern Powder River Basin, and the Montana Powder River Basin (fig. 4; Luppens and others, 2015). During the course of the assessment, stratigraphic data for thousands of recently completed coal-bed methane and oil and gas wells were incorporated, thereby improving stratigraphic correlations in the basin and the corresponding assessment of coal resources. Unlike the Illinois Basin coal resource assessment, coal quality data were not compiled as part of the most recent Powder River Basin resource assessment, and no new coal sampling was conducted. However, trace-element data were obtained for the Wyodak and Big George coals, two of the most important producers, in three (of 37) cores sampled from 1999 to 2003 (Stricker and others, 2007). For 129 samples in these three cores, mean mercury values of 0.07 ppm for the Middle/Lower Wyodak $(n=79)$ and 0.09 ppm for the Big George $(n=50)$ coals were obtained, counting non-detects as 50 percent of the detection limit (Stricker and others, 2007, table 4).

\section{Potential for Further Investigation}

Available data for the Powder River Basin indicate that mean mercury and halogen contents of Powder River Basin coals are low (Hg < 0.1 ppm; Cl < 100 ppm; Stricker and others, 2007). Mean sulfur contents range from 0.15 to 0.75 percent in various parts of the basin (Luppens and others, 2015). As such, these coals are generally shipped without preparation. Attempts to further reduce mercury contents by conventional means have been largely unsuccessful (for example, Palmer and others, 2000). Reduction of mercury in Powder River Basin coals by thermal pretreatment is more promising (Merriam, 1993; Guffey and Bland, 2004), but this approach is unlikely to be applied on a commercial scale. Characterization of these coals is complicated by their high moisture contents, which can be a source of error if not properly determined (Luppens, 2011), and low halogen contents, which may be below detection by widely used ASTM methods. Nonetheless, more extensive investigation of traceelement variation in Powder River Basin coals, including more detailed investigation of regional and stratigraphic controls, could complement past USGS investigations, including the recent coal resource assessment. It would be particularly useful to determine whether trace element differences parallel known variations in ash yield and sulfur contents throughout the Basin. 


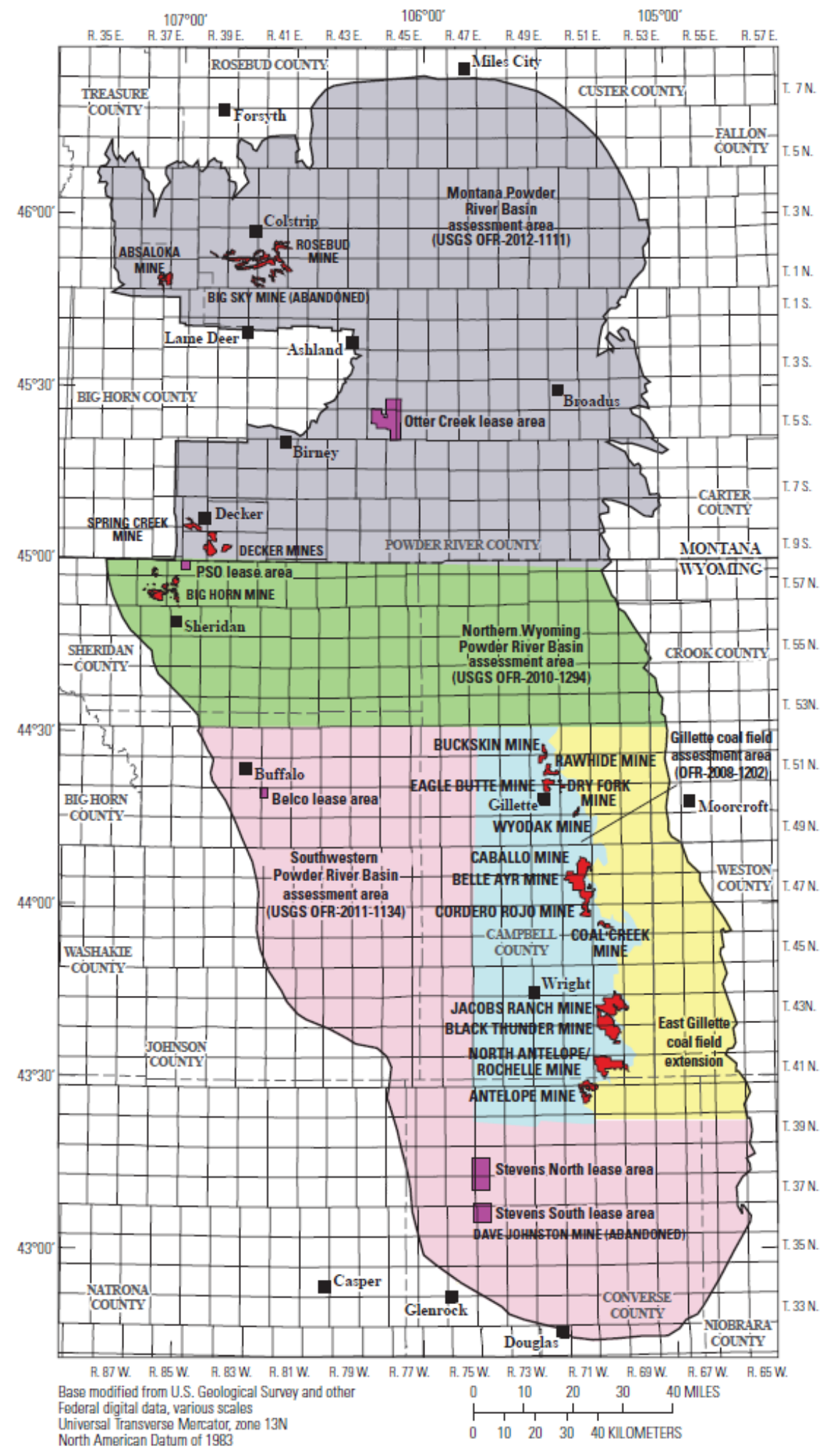

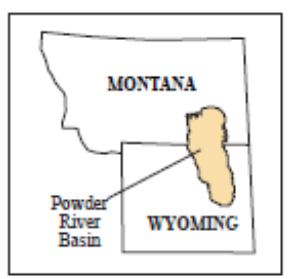

LOCATION MAP

Figure 4. Map showing mines and coal fields in the Powder River Basin (from Luppens and others, 2015). 


\section{Summary and Conclusions}

Input from an expert panel on mercury from coal combustion provided guidance for new U.S. Geological Survey (USGS) coal quality studies under the Mercury and Air Toxics Standards (MATS) framework. According to the panel, the USGS should place greater emphasis on delivered coal and coal feeding the boiler, as opposed to in-ground sampling. However, new in-ground or as-mined sampling may still be useful in defining the extent of element variability within a given coal bed, which would be useful to utility operators in planning for variation likely to be encountered in using a specific coal. The panel identified the Illinois Basin and the Powder River Basin as appropriate targets for new USGS coal quality investigations focused on mercury and chlorine in addition to the other elements whose emissions are expected to be limited under MATS. Prior USGS coal resource assessments provide useful background for new studies in both basins. Use of mercury isotopic data and laser-ablation inductively coupled plasma mass spectrometry (ICP-MS) analysis of mineral phases, such as pyrite, not previously included in USGS coal assessment studies may be especially helpful in understanding regional (or basin-scale) controls on coal geochemistry. Inclusion of new and existing data in a geographic information system (GIS) format may be useful for identifying basin-scale trends and in predicting expected variations in coal quality.

\section{References}

Aruscavage, P.J., and Moore, R., 1989, The determination of mercury in whole coal by cold-vapor atomic absorption spectrometry: in, Golightly, D.W., and Simon, F.O., eds. Methods for sampling and inorganic analysis of coal: U.S. Geological Survey Bulletin 1823, p. 55-57. [Also available at http://pubs.usgs.gov/bul/1823/report.pdf.]

ASTM International, 2013, Standard test method for total chlorine in coal by the oxygen bomb combustion/ion selective electrode method: West Conshohocken, Pa., ASTM International, ASTM D4208-13, accessed April 27, 2015, at www.astm.org.

ASTM International, 2015, Standard test method for determination of chlorine in coal by oxidative hydrolysis microcoulometry: West Conshohocken, Pa., ASTM International, ASTM D6721-01(2015) accessed April 27, 2015, at www.astm.org.

Bragg, L.J., Oman, J.K., Tewalt, S.J., Oman, C.L., Rega, N.H., Washington, P.M., and Finkelman, R.B., 1998, Coal quality (COALQUAL) database-Version 2.0: U.S. Geological Survey Open-File Report 97-134, CD-ROM. [Also available at http://pubs.usgs.gov/of/1997/of97-134/.]

Carroll, C., 2014, Wyoming’s coal resource summary report: Wyoming State Geological Survey, 4 p., accessed May 1, 2015, at http://www.wsgs.wyo.gov/products/2014-coal-summary.pdf.

Demir, I., Ruch, R.R., Damberger, H.H., Harvey, R.D., Steele, J.D., and Ho, K.K., 1997, Environmentally critical elements in channel and cleaned samples of Illinois coals: Fuel, v. 77, no. 1/2, p. 95-107.

Denny, F.B., Guillemette, R.N., and Lefticariu, L., 2015, Rare earth mineral concentrations in ultramafic alkaline rocks and fluorite within the Illinois-Kentucky Fluorite District: Hicks Dome cryptoexplosive complex, southeast Illinois and northwest Kentucky (USA), in Lasemi, Z., ed., Proceedings of the 47th Forum on the Geology of Industrial Minerals: Illinois State Geological Survey Circular 587, 16 p., accessed March 13, 2015, at https://www.isgs.illinois.edu/sites/isgs/files/files/publications/ofs2011-02-230-FULL.pdf.

Deonarine, Amrika, Kolker, Allan, and Doughten, Michael, 2015, Trace elements in coal ash: U.S. Geological Survey Fact Sheet 2015-3037, 6 p. [Also available at http://pubs.usgs.gov/fs/2015/3037/pdf/fs2015-3037.pdf.] 
Diehl, S.F., Goldhaber, M.B., Koenig, A.E., Lowers, H.A., and Ruppert, L.F., 2012, Distribution of arsenic, selenium, and other trace elements in high pyrite Appalachian coals_Evidence for multiple episodes or pyrite formation: International Journal of Coal Geology, v. 94, p. 238-249.

EPRI, 2000, Technical evaluation-Analysis of chlorine in coal by oxidative hydrolysis microcoulometry: Palo Alto, Calif., EPRI, product ID 1000846.

Fiscor, Steve, 2012, The Illinois Basin supply-side story: Coal Age, January 6, 2012, accessed May 21, 2015, at http://www.coalage.com/features/1605-the-illinois-basin-supply-side-story.html. Gluskoter, H.J., 1967, Chlorine in coals of the Illinois Basin: Transactions of the Society of Mining Engineers of American Institute of Mining, Metallurgical and Petroleum Engineers, Inc. (AIME), December, 1967, p. 373-379.

Gluskoter, H.J., and Rees, O.W., 1964, Chlorine in Illinois coal: Illinois State Geological Survey Circular 372, 23 p. [Also available at http://www.isgs.illinois.edu/publications/c372.]

Gluskoter, H.J., Ruch, R.R., Miller, W.G., Cahill, R.A., Dreher, G.B., and Kuhn, J.K., 1977, Trace elements in coal-Occurrence and distribution: Illinois State Geological Survey Circular 499, 154 p. [Also available at http://library.isgs.illinois.edu/Pubs/pdfs/circulars/c499.pdf.]

Goldhaber, M.B., Lee, R.C., Hatch, J.R., Pashin, J.C., and Treworgy, J., 2003, Role of large scale fluidflow in subsurface arsenic enrichment, in Welch, A.H., and Stollenwerk, K.G., eds., Arsenic in ground water, geochemistry and occurrence: Boston, Kluwer Academic Publishers, 488 p.

Golightly, D.W., Dorrzapf, A.F., Jr., Mays, R.E., Fries, T.L., and Conklin, N.M., 1987, Analysis of geologic materials by direct-current arc emission spectrography and spectrometry, chap. A, of Baedecker, P.A., ed., Methods for geochemical analysis: U.S. Geological Survey Bulletin 1770, p. A1-A13. [Also available at http://pubs.usgs.gov/bul/1770/report.pdf.]

Guffey, F.D., and Bland, A.E., 2004, Thermal pretreatment of low-ranked coal for control of mercury emissions: Fuel Processing Technology, v. 85, p. 521-531.

Hatch, J.R., and Affolter, R.H., 2002, Resource assessment of the Springfield, Herrin, Danville, and Baker Coals in the Illinois Basin: U.S. Geological Survey Professional Paper 1625-D, CD-ROM. [Also available at http://pubs.usgs.gov/pp/p1625d/.]

Hatch, J.R., Jacobson, R., Mastalerz, M., Andrews, W., Weisenfluh, J., Affolter, R.H., and Gunther, G., 2002, Resource assessment of the Springfield, Herrin, Danville, and Baker Coals in the Illinois Basin: U.S. Geological Survey Fact Sheet 072-02, 4 p., accessed March 19, 2015, at http://pubs.usgs.gov/fs/fs-0072-02/.

Heyl, A.V., Brock, M.R., Jolly, J.L., and Wells, C.E., 1965, Regional structure of the southeast Missouri and Illinois-Kentucky mineral districts: U.S. Geological Survey Bulletin 1202-B, 20 p. [Also available at http://pubs.usgs.gov/bul/1202b/report.pdf.]

Hower, J.C., and Gayer, R.A., 2002, Mechanisms of coal metamorphism-Case studies from Paleozoic coalfields: International Journal of Coal Geology, v. 50, p. 215-245.

Hower, J.C., Mastalerz, M., Drobniak, A., Quick, J.C., Eble, C.F., and Zimmerer, M.J., 2005, Mercury content of the Springfield coal, Indiana and Kentucky: International Journal of Coal Geology, v. 63, p. 205-227.

Hower, J.C., Riley, J.T., Thomas, G.A., and Griswold, T.B., 1991, Chlorine in Kentucky coals: Journal of Coal Quality, v. 10, no. 4, p. 152-158.

Huggins, F.E., and Huffman, G.P., 1995, Chlorine in coal-An XAFS spectroscopic investigation: Fuel, v. 74, no. 4, p. 556-569. 
Huggins, F.E., Seidu, L.B.A., Shah, N., Huffman, G.P., Honaker, R.Q., Kyger, J.R., Higgins, B.L.,

Robertson, J.D., Pal, S., and Seehra, M.S., 2009, Elemental modes of occurrence in an Illinois \#6 coal and fractional prepared by physical separation techniques at a coal preparation plant: International Journal of Coal Geology, v. 78, p. 65-76.

Hutson, N., 2015, Regulations, in, Granite, E., Senior, C., and Pennline, H., eds., Mercury control for coal-derived gas streams: Wiley-VCH, p. 45-50.

Illinois State Geological Survey, 2014, Illinois coal resource shapefiles: Illinois State Geological Survey Web site, accessed December 22, 2014, at http://isgs.illinois.edu/research/coal/shapefiles. [Available as all-coal-mines.zip file download.]

Indiana Geological Survey, 2015, CMIS—downloads, downloads and metadata, coal mine layers: Indiana Geological Survey Web site, accessed June 6, 2015, at https://igs.indiana.edu/CMIS/Downloads.cfm. [Available as Coal_Mines_Surface.zip and Coal_Mines_Underground.zip file downloads.]

James, Steve, 2012, Coal makes a comeback in Illinois Basin in U.S.: Reuters, May 11, 2012, accessed May 21, 2015, at http://www.reuters.com/article/2012/05/11/coal-illinoisidUSL1E8G2IWD20120511.

Kentucky Geological Survey, 2015, Downloads: available maps and digitized mined out areas (ESRI shapefile format): Kentucky Mine Mapping Information System Web site, accessed September 25, 2015, at http://minemaps.ky.gov/Default.aspx?Src=Downloads. [Available as westseams_dd83.zip file download.]

Kolker, A., 2012, Minor element distribution in iron disulfides in coal—A geochemical review: International Journal of Coal Geology, v. 94, p. 32-43.

Kolker, A., and Quick, J.C., 2015, Mercury and halogens in coal, in Granite, E., Senior, C., and Pennline, H., eds., Mercury control for coal-derived gas steams: Wiley-VCH, p. 13-44.

Kolker, A., Senior, C.L., and Quick, J.C., 2006, Mercury in coal and the impact of coal quality on mercury emissions from combustion systems: Applied Geochemistry, v. 21, p. 1821-1836.

Kolker, A., Quick, J.C., Senior, C.L., and Belkin, H.E., 2012, Mercury and halogens in coal- their role in determining mercury emissions from coal combustion: U.S. Geological Survey Fact Sheet 20123122, 6 p. [Also available at http://pubs.usgs.gov/fs/2012/3122/.]

Kolker, A., Senior, C., van Alphen, C., Koenig, A., and Geboy, N., in press, Mercury and trace element distribution in density separates of a South African Highveld (\#4) coal-Implications for mercury reduction and preparation of export coal: International Journal of Coal Geology .

Lefticariu, L., Blum, J.D., and Gleason, J.D., 2011, Mercury isotopic evidence for multiple mercury sources in coal from the Illinois Basin: Environmental Science and Technology, v. 45, p. 1729.

Luppens, J.A., 2011, A critical review of published coal quality data from the southwestern part of the Powder River Basin, Wyoming: U.S. Geological Survey Open File Report 2011-1148, 23 p., accessed June 4, 2015 at http://pubs.usgs.gov/of/2011/1148/.

Luppens, J.A., Scott, D.C., Osmonson, L.M., Haacke, J.E., and Pierce, P.E., 2013, Assessment of coal geology, resources, and reserve base in the Powder River Basin, Wyoming and Montana: U.S. Geological Survey Fact Sheet 2012-3143, 6 p., accessed June 4, 2015, at http://pubs.usgs.gov/fs/2012/3143/fs-2012-3143.pdf.

Luppens, J.A., Scott, D.C., Haacke, J.E, Osmonson, L.M., and Pierce, P.E., 2015, Coal geology and assessment of coal resources and reserves in the Powder River Basin, Wyoming and Montana: U.S. Geological Survey Professional Paper 1809, 218 p., accessed June 8, 2015, at http://pubs.usgs.gov/pp/1809/. 
Mastalerz, M. and Drobniak, A., 2005, Vertical variations of mercury in Pennsylvanian coal beds from Indiana: International Journal of Coal Geology, v. 63, p. 36-57.

Merriam, N.W., 1993, Removal of mercury from Powder River Basin coal by low-temperature thermal treatment: Report prepared by Western Research Institute for U.S. Department of Energy, WRI-93-R021, 23 p.

Miller, J.W., 2014, The future of coal—Scrubbing technology revives Midwest mines: Wall Street Journal, January 8, 2014, accessed May 21, 2015, at http://www.wsj.com/articles/SB10001424052702303332904579228161981168296.

O’Leary, R.M., 1997, Determination of mercury and selenium in eight Argonne Premium Coal samples by cold-vapor and hydride-generation atomic absorption spectrometry, in Palmer, C.A., ed., The chemical analysis of Argonne Premium Coal samples: U.S. Geological Survey Bulletin 2144, p. 51-55. [Also available at http://pubs.usgs.gov/bul/2144/report.pdf.]

Palmer, C.A., Mroczkowski, S. J., Kolker, A., Finkelman, R.B., and Bullock, J.H., Jr., 2000, Chemical analysis and modes of occurrence of selected trace elements in a Powder River Basin coal and its corresponding simulated cleaned coal: U.S. Geological Survey Open File Report 00-323, 53 p. [Also available at http://pubs.usgs.gov/of/2000/0323/report.pdf.]

Peng, B., Wu, D., Lai, J., Xiao, H., and Li, P., 2012, Simultaneous determination of halogens (F, C., Br, and I) in coal using pyrohydrolysis combined with ion chromatography: Fuel, v. 94, p. 629-631.

Pirrone, N., Cinnirella, S., Dastoor, A., Ebinghaus, R., Gratz, L., Hedgecock, I., Sprovieri, F., and Travnikov, O., 2013, Atmospheric pathways, transport and fate, chap. 3 of AMAP/UNEP Technical background report for the global mercury assessment, 2013: Arctic Monitoring and Assessment Programme, Oslo, Norway/UNEP Chemicals Branch, Geneva Switzerland, p. 38-68. [Also available at http://apps.unep.org/publications/pmtdocuments/AmapUnepTechBackRepGMA2013.pdf.]

Ruch, R.R., Gluskoter, H.J., and Kennedy, E.J., 1971, Mercury content of Illinois coals: Illinois State Geological Survey, Environmental Geology Notes, no. 43, 15 p. [Also available at http://library.isgs.illinois.edu/Pubs/pdfs/egs/eg043.pdf.]

Ruppert, L.F., and Ryder, R.T., eds., 2014, Coal and petroleum resources in the Appalachian basin; Distribution, geologic framework, and geochemical character: U.S. Geological Survey Professional Paper 1708, CD-ROM. [Also available at http://pubs.usgs.gov/pp/1708/.]

Senior, C., 2015, Mercury behavior in combustion systems, in Granite, E., Senior, C., and Pennline, H., eds., Mercury control for coal-derived gas steams: Wiley-VCH, p. 111-131.

Stricker, G.D., Flores, R.M., Trippi, M.H., Ellis, M.S., Olson, C.M., Sullivan, J.E., and Takahashi, K.I., 2007, Coal quality and major, minor, and trace elements in the Powder River, Green River, and Williston basins, Wyoming and North Dakota: U.S. Geological Survey Open-File Report 2007-1116, 31 p. and 4 appendixes , accessed June 10, 2015, at http://pubs.usgs.gov/of/2007/1116/.

Supreme Court of the United States, 2015, Michigan vs. the U.S. Environmental Protection Agency, accessed September 25, 2015, at http://www.supremecourt.gov/opinions/14pdf/14-46_bqmc.pdf.

Taggart, Jr., J.E., Lindsay, J.R., Scott, B.A., Vivit, D.V., Bartel, A.J., and Stewart, K.C., 1987, Analysis of geologic materials by wavelength-dispersive X-ray fluorescence spectrometry, in Baedecker, P.A., ed., Methods for geochemical analysis: U.S. Geological Survey Bulletin 1770, Chapter E, 19 p. [Also available at http://pubs.usgs.gov/bul/1770/report.pdf.]

U.S. Energy Information Administration, variously dated, Annual coal report [Years 2004 to 2013]: Accessed May 19, 2015, at http://www.eia.gov/coal/annual/.

U.S. Energy Information Agency, 2014, State profiles, Wyoming: Accessed June 4, 2015, at http://www.eia.gov/state/analysis.cfm?sid=WY. 
U.S. Environmental Protection Agency (EPA), 2000, Mercury determination regulatory finding on the emissions of hazardous air pollutants from electric utility steam generating units: Federal Register, v. 65, no. 245, p. 79825-79831, December 20, 2000, accessed May 27, 2015, at http://www.epa.gov/mats/utilfind.pdf.

U.S. Environmental Protection Agency (EPA), 2003, U.S. Environmental Protection Agency, Electric utility steam generating units section 112 rule making - Coal analysis results: Accessed December 2011 at http://www.epa.gov/ttn/atw/combust/utiltox/utoxpg.html. [Four zipped EXCEL files.]

U.S. Environmental Protection Agency (EPA), 2005, 2005 National Emissions Inventory data \& documentation, accessed June 2, 2015, at http://www.epa.gov/ttn/chief/net/2005inventory.html.

U.S. Environmental Protection Agency (EPA), 2007, Mercury in solids and solutions by thermal decomposition, amalgamation, and atomic absorption spectrophotometry: U.S. EPA Method 7473, 17 p., accessed May 21, 2015, at http://www.epa.gov/osw/hazard/testmethods/sw846/pdfs/7473.pdf.

U.S. Environmental Protection Agency (EPA), 2011a, Air toxics standards for utilities-MATS ICR data (EGU_ICR_PartI_and_PartII): Accessed March 2011 at http://www.epa.gov/ttn/atw/utility/utilitypg.html. [ACCESS data file download.]

U.S. Environmental Protection Agency (EPA), 2011b, Air toxics standards for utilities-MATS ICR data (EGU ICR Part III): Accessed March 2011 at http://www.epa.gov/ttn/atw/utility/utilitypg.html. [ACCESS data file download.]

U.S. Environmental Protection Agency (EPA), 2012, National emission standards for hazardous air pollutants from coal- and oil-fired electric utility steam generating units-Final rule: Federal Register, v. 77, no 32, p. 9304-9512, February 16, 2012, accessed May 21, 2015, at http://www.epa.gov/ttn/atw/utility/fr16fe12.pdf.

Willman, H.B., Atherton, E., Buschbach, T.C., Collinson, C., Frye, J.C., Hopkins, M.E., Lineback, J.A., and Simon, J.A., 1975, Handbook of Illinois stratigraphy: Illinois State Geological Survey Bulletin 95, 261 p. [Also available at http://library.isgs.illinois.edu/Pubs/pdfs/bulletins/bul095.pdf.] 


\section{Appendix 1.}

Table 1-1. Panel members and their expertise.

[CAER, University of Kentucky Center for Applied Energy Research; EERC, University of North Dakota Energy and Environmental Research Center; EPA, U.S. Environmental Protection Agency; Hg, mercury; inst., institute; MATS, Mercury Air Toxics Standards; min. info. tm., minerals information team; univ., university; USGS, U.S. Geological Survey]

\begin{tabular}{|c|c|c|c|c|}
\hline Name & Affiliation & Expertise & $\begin{array}{c}\text { Call } \\
\text { participant }\end{array}$ & $\begin{array}{c}\text { Survey } \\
\text { participan }\end{array}$ \\
\hline Joseph Bittinger & American Electric Power & Utility operator & & $\mathrm{X}$ \\
\hline Ramsay Chang & Electric Power Research Inst. & Energy geochemistry & & $\mathrm{X}$ \\
\hline Debalina Dasgupta & Illinois Clean Coal Institute & Illinois coal industry & $\mathrm{X}$ & \\
\hline Dan Duellman & American Electric Power & Utility operator & $\mathrm{X}$ & $\mathrm{X}$ \\
\hline Stan Durkee & EPA & EPA research \& regulations & $\mathrm{X}$ & \\
\hline Tony Facchiano & Electric Power Research Inst. & Energy geochemistry & & $\mathrm{X}$ \\
\hline Nick Geboy & USGS-Reston & Hg analytical methods & $\mathrm{X}$ & \\
\hline Naomi Goodman & Electric Power Research Inst. & Energy geochemistry & & $\mathrm{X}$ \\
\hline Kevin Henke & University of Kentucky CAER & Hg researcher & $\mathrm{X}$ & $\mathrm{X}$ \\
\hline James Hower & University of Kentucky CAER & Kentucky coal and coal ash & & $\mathrm{X}$ \\
\hline Kevin Jones & USGS-Reston Energy & Geochemistry, call recorder & $\mathrm{X}$ & \\
\hline Wojciech Jozewicz & Arcadis-USA EPA contractor & Coal-related mercury studies & & $\mathrm{X}$ \\
\hline Allan Kolker & USGS-Reston Energy & Hg in coal- panel chair & $\mathrm{X}$ & \\
\hline Liliana Lefticariu & Southern Illinois Univ. & Hg isotopes in coal & $\mathrm{X}$ & $\mathrm{X}$ \\
\hline Leonard Levin & Electric Power Research Inst. & Hg environmental studies & $\mathrm{X}$ & $\mathrm{X}$ \\
\hline Pat Malone & American Electric Power & Utility operator & $\mathrm{X}$ & $\mathrm{X}$ \\
\hline Brian Marshall & USGS-Denver Energy Labs & Analytical approaches & $\mathrm{X}$ & \\
\hline George Offen & Electric Power Research Inst. & Energy geochemistry & & $\mathrm{X}$ \\
\hline Ricardo Olea & USGS-Reston Energy & Geostatistical approaches & $\mathrm{X}$ & $\mathrm{X}$ \\
\hline John Pavlish & Univ. North Dakota EERC & EPA MATS; Hg in the boiler & $\mathrm{X}$ & \\
\hline Jacob Pearson & American Electric Power & Utility operator & $\mathrm{X}$ & $\mathrm{X}$ \\
\hline Jeff Quick & Utah Geological Survey & Utah coal/EPA Hg databases & $\mathrm{X}$ & $\mathrm{X}$ \\
\hline Connie Senior & ADA-ES, Inc. & Hg in combustion systems & $\mathrm{X}$ & \\
\hline Hendrik van Oss & USGS-Reston Min. Info. Tm. & $\mathrm{Hg}$ in the cement industry & & $\mathrm{X}$ \\
\hline Peter Warwick & USGS-Reston Energy & USGS resource assessments & $\mathrm{X}$ & $\mathrm{X}$ \\
\hline
\end{tabular}


